\title{
The Condition and Consequences of Adultery in Bangladesh
}

\author{
Nelufer Yesmen ${ }^{1 *}$, Md. Mazharul Hasan Nahid ${ }^{2}$
}

${ }^{1}$ Assistant Professor, Department of Criminology and Police Science, Mawlana Bhashani Science and Technology University, Santosh, Tangail-1902, Bangladesh

${ }^{2}$ Graduate Student, Department of Criminology and Police Science, Mawlana Bhashani Science and Technology University, Santosh, Tangail-1902, Bangladesh

DOI: $10.36348 /$ sijlcj.2020.v03i01.004

| Received: 03.01.2020 | Accepted: 10.01.2020 | Published: 24.01 .2020

*Corresponding author: Nelufer Yesmen

\section{Abstract}

Ethical decadences are increasing in our contemporary society day by day. Adultery is one of the examples of moral degradation. This study investigates the present condition and consequences of adultery and finds women commit adultery with ex-lover, relative, known person and in some cases with unknown person. Social media such as: facebook, whats app, viber, imo etc. are common tools to commit adultery in now days. Lack of moral sense, degenerate culture, lack of family bonding, technological development are the main causes for committing adultery and as consequences murder, divorce, spouse violence, domestic violence, flogging, sexually transmitted diseases, honor-killing, stoning etc are the result of adultery. It conducted based on secondary resources which are collected from books, articles, newspapers and authentic websites. This study tries to describe adultery through opportunity theory where adultery is thought a result of getting more opportunity. Legal authorities can get a clear idea about the conditions and consequences of adultery which can help the government to create policy to decrease adultery in Bangladesh.

Keywords: Adultery, Extra marital affair, punishment, law, loopholes of law, violent crime.

Copyright @ 2020: This is an open-access article distributed under the terms of the Creative Commons Attribution license which permits unrestricted use, distribution, and reproduction in any medium for non-commercial use (NonCommercial, or CC-BY-NC) provided the original author and source are credited.

\section{INTRODUCTION}

Today's fast spaced world is increasingly characterized by technology but lost the morality day by day. Little research has been carried out in the area of adultery or extra marital affairs. Although some researchers have paid attention to know the adultery related law and the causes of adultery [1-5, 3]. Marriage is both a civil contract in case of Muslim marriage and a holysacrament in case of other religions and the society has certain thoughtsabout the same [6]. Couple sort into marriage according to the characteristics, such as similar religion, ethnicity, and education to enhance their marriage quality and stability [7]. In modern society, marital satisfaction stems mainly from a couple's consumption in leisure activities. For social, cultural and psychological reasons, extra marital affairs and adultery may have different impacts on marital satisfaction and mental well-being for different couples .Adultery is a term which derived from the Latin term 'adulterium' where'ad' means 'towards' and 'alter' means 'other'. The actual definition of adultery may vary in different jurisdictions. Adultery means sexual intercourse between amarried woman and man. From our country perspective, there is a difference between adultery and extramarital affairs. The difference is very little but important to know. To commit adultery according to The Penal code, 1860 , it is must to the women become a wife of another man. Without the condition the sexual intercourse will not count as adultery. On the other hand to commit extra marital affairs, the woman or man one of them need to be married. But in many western countries there is no actual difference between "adultery" and "extra marital affairs." [1]. In this study adultery and extra marital affairs are used exchangeable. Adultery is certainly a moral crime and is thought-out a sin by almost all religions .Interaction between law and sex has posedmany problems in the society. Sex is a basic urge to allhuman beings. The urge is so strong that it iscontrolled by various social means, such as law,religion, morals, customs, public opinion etc. .A high proportion of all first marriages in the United States are likely to end in divorce because of extra marital affairs [8].With thepassage of time, religion as a means of social controlhas become weak and law emerged as a strong and themost effective means of social control. Sexual valuessought to be controlled by law are those which arepermissible by religion generally. It is considered as a good ground of divorce through all over the world. Adultery is an 
unlawfulrelationship engaged in by a spouse outside his/her marriage. Adultery occurs different types of crime in national and international perspectives. Murder, divorce, spouse violence, domestic violence, flogging, sexually transmitted diseases, honor killing, stoning are the very common consequences of adultery[1]. Marriage is the legalizing of a relationship between a man and a woman to which the society gives its approval. Marriage places each partner under legal and social obligations to oneself and to the society. Marriage is a union of a man and a woman who agree to live together as husband and wife [9]. It also permits to fulfill one fundamental sexual needs but now a days, sexual relation without marriage are increasing [3]. Durex's Global Sex Survey found that worldwide 22\% of people surveyed admitted to have had extramarital sex [10]. Kinsey found in his studies that $50 \%$ of males and $26 \%$ of females had extramarital sex at least once during their lifetime. Depending on studies, it was estimated that $26-50 \%$ of men and $21-38 \%$ of prevalence women or $22.7 \%$ of men and $11.6 \%$ of women had extramarital sex [11]. Other authors say that between $20 \%$ and $25 \%$ of Americans had sex with someone other than their spouse [2]. Three 1990s studies in the United States, using nationally representative samples have found that about $10-15 \%$ of women and $20-25 \%$ of men admitted to having engaged in extramarital sex [5]. Adultery is a very known form of extramarital sex. Adultery can be a morally reprehensible act as it involves deception, betrayal, the breaking of promises, and the causing of emotional pain [12]. Divorce rate is increasing for adultery .For example, In the United States, the divorce rate had risen steadily from 2.5 per 1000 population in 1966 to a peak of 5.3 in 1981[4].

Approximately 150,000 persons have been prosecuted annually for the crime of adultery since the 1980s [9]. In Bangladesh, divorce rate is also increasing because of adultery. From the statistics of Dhaka city corporation from 2010-2016, the total divorce amount is 52,000 (bdnews24.com, 10.06.2015). In most Western countries, adultery itself is no longer a criminal offense but may still have legal consequences particularly in divorce cases. In only two western countries, Austria and Switzerland criminalize adultery (Austrian Penal Code, Art. 194, Swiss Penal Code, Art. 214.) [31]. In contrast, Denmark (1930), Sweden (1937), Japan (1947), Germany (1969) and France (1975) have all abolished the crime of adultery. Far eastern countries such as: China, Japan and North Korea are not criminalizing adultery [12]. In Muslim countries that follow Shariah law for criminal justice, criminalize adultery and the punishment for adultery may be stoning [13]. In India and Bangladesh, law and punishment of adultery were completely same. But recently the supreme court of India ruled that adultery is not a crime in their country (The Guardian, 27.09.2018) .So, now it is a crime in Bangladesh and many other Muslim populated countries. Different types of crimes such as honor killing, murder, violence between adulterous couple occurs because of adultery. In Bangladesh violent crimes like (murder, rape) is also increasing devastatingly for adultery. Especially adultery is the fundamental cause of spouse related murder. (Kalerkantha, 12.June.2017). All of these studies describe about the law, punishment, causes of adultery. It is also told that whether adultery is a crime or not all over the world. The newspaper of our country sometimes present some news of violent crime which is caused by adultery. But actually there is no specific research about the present condition and consequences of adultery in our country. This study focus on the present condition of adultery and the devastating consequences of this crime in Bangladesh. Actually, this study helps a lot to discourse adultery in the country.

The objectives of this study are as follows:

- To explore the present condition of adultery.

- To identify the consequences of adultery.

\section{METHODOLOGY}

Methodology is the systematical analysis of any methods applied to a field study. This is a descriptive study which is based on secondary data. These data are collected from books, articles, reports, newspapers, publications and some authentic websites. These information are collected according to research objectives.

\section{FINDINGS}

Findings of the study describes according to their objectives. At first, this paper discuss about the actual situation of adultery. Present situation describes the nature and ways of adultery where cultural decay, moral devastation for adultery is also discussed. Then the laws and punishment system for adultery in different countries are discussed. At last, the paper also discusses the consequences of adultery.

\section{Present condition of adultery}

In past, adultery was like a taboo in every society. Extra marital affairs, incest were not a normal thing. So society discourages people to involve in adultery. All over the world extra marital sex and adultery is increasing day by day [10]. People are engaged in adultery in different ways. Now a day's most of the people are committing adultery by their known persons. Sometimes the woman commits adultery with their ex-lover, relatives, and relatives in law, neighbors and with other known persons. From different newspapers it is also known that they can also commit adultery with unknown person by using face book, imo, whats app, viber etc. In most of the adultery cases, the husband of the adultery woman does not stay with his wife [14]. He may be stay in abroad or other place for his own job depriving his partner from fundamental sexual needs. For this reason, his wife 
fulfilling her sexual needs involving adultery with other people. Adultery involved people lost their moral laws, theybreak up their familyand they also ruin their family and children life. In some serious case they can even commit murder for adultery. They can kill their spouses and even their children too. From different news, it is seen that wife with the help of her adultery partner kill their husband, husbands kill their wife and parents kill their children too. Domestic violence is also increasing for adultery. It is a moral loss for people ( (Bindu Vasudevan).

\section{Laws and punishment of adultery: a comparative study}

Some countries of the world think adultery is not a crime and many countries count adultery is a good ground for divorce. It was a crime in Japan until 1947 and until 2015 in South Korea. Now adultery is not a crime in People's Republic of China but is a ground for divorce (Marriage Law of thePeople's Republic of China,Article 32). There are currently proposals to decriminalize adultery in the Philippines (Philippine eLegal Forum, 2001). Adultery is no longer a crime in most of the European countries. Among the last Western European countries to repeal their laws against adultery were Italy (1969), Malta (1973), Luxembourg (1974), France (1975), Spain (1978), Portugal(1982), Greece (1983), Belgium (1987) (Kuk C,2002).In most Communist countriesadultery is not a crime .In Turkey, there wereproposals to introduce agender-neutral adultery law in 2004. Until the 1990s, most Latin American countries had laws against adultery. Adultery has been decriminalized in most of these countries including Paraguay (1990), Chile(1994), Argentina (1995), Nicaragua (1996), Brazil (2005) and Haiti(2005).The adultery law of the Federal Criminal Code of Mexico was repealed in 2011 [15]. Adultery is not a crime in Australia. Under federal law enacted in 1994, sexual conduct between consenting adults (18 years of age or older) is their private matter throughout Australia [16]. In the United States, laws vary from state to state. As of 2017, adultery remains a criminal offense in 24 states but prosecutions are rare. Although adultery laws are mostly found in the conservative states (especially Southern states). (New York Penal Law Section no. 255). On the other hand, some countries think adultery is a serious crime. Two western countries, Austria and Switzerland, criminalize adultery (Austrian Penal Code, Art. 194\& Swiss Penal Code, Art. 214.). In Muslim countries that follow Shariah law for criminal justice think adultery is a very serious crime. These countries give very serious punishment for adultery .Most of the Shariah law based Muslim countries give death penalty for adultery and the process of giving punishment for adultery is stoning[13]. In Pakistan, adultery is a crime under the Hudood Ordinance and its punishment is death. In Bangladeshi law, adultery is defined as sex between a man and a married woman without the consent of the woman's husband. The man is prosecutable and can be sentenced for up to five years. (The Penal Code, 1860, Section no.497). Legal definitions of adulteryvaries from place to place. In the traditional English common law, adultery differs in nearly every legal system, the common theme is sexual relations outside of marriage is a serious violation (Moya). In New Yorkdefines an adulterer as a person who engages in sexual intercourse with another person at a time when he has a living spouse or the other person has a living spouse. In North Carolina defines adultery as occurring when any man and woman lewdly and lasciviously associate, bed, and cohabit together (North Carolina Statute,184).Minnesota law provides, "when a married woman has sexual intercourse with a man other than her husband, whether married or not both are guilty of adultery."(Minnesota Statute section609). In Canada, though the written definition in the Divorce Act refers to extramarital relations with someone of the opposite sex. On the other hand, In Bangladesh adultery is the sexual intercourse of a man with a married woman without the consent of her husband when such sexual intercourse does not amount to rape. It is a noncognizable, non-bailable criminal offence. (The Penal code, 1860).

\section{The injustice law situation in case of adultery in Bangladesh}

The spouses are and ought to be at a freedom to choose their own terms of the contract. A criminal offence in Bangladesh under Section 497 of The Penal Code, 1860 is adultery which is considered to be an invasion to the right of the husband over his married wife. It is an offence which is committed by a third person against a husband in respect of his wife and of which man can alone be held liable for the offence. Sexual intercourse with an unmarried woman or with a widow or a divorcee woman or with a woman, whose husband gave his consent doesnot constitute the offence of adultery. However, it is not necessary that the otherperson be a married person. (Nurul Haq Bahadur V. Bibi Sakina and others, 1985 BLD 269). This paper argues that the man should not be the only one within the ambit of the Code but that the wife should also be guilty of adultery. The law basically provides that the offence ofadultery is committed only by man (third party) who had sex with thewife of another man without the husbands consent and women cannot bepunished, even as an abettor. Only married womanand third person take part in this offence. The woman is the consentingparty to the offence. She also takes active part in the sexual intercoursevoluntarily and most probably with sexual desire, love and affection. (Samraj Nadar v.Abraham Nadachi, AIR 1970 Mad. 434, 457).Wife of another man cannot sue any case against the man. This is also very important problem of the section. The section does not provide any remedy to a woman whose husband has committed adultery with another woman which is also a violation of gender neutrality clause provided in constitution. The constitutional validity of the sectionhas been challenged 
on the grounds that it violates the fundamental rightsof a man under Article 27 of the Constitution of the People's Republic ofBangladesh which states that "All citizens are equal before law and areentitled to equal protection of law". Yet it is clearly observedthat the legislature is making discrimination on the basis of sex on thepretext of giving 'protective discrimination' to the women. The Section 497 of thePenal Code, 1860 is nothing but a violation of equality clause under theConstitution of the People's Republic of Bangladesh. It is high time that this lawshould be amended to meet the present circumstances. However, Section 497 should not be removed from the Code butit is recommended that both the man and woman should be made guilty and sue case against their partners [6].

Adultery or extra marital affairs is not a good culture for our country. The western and Indian culture are playing a leading role in moral degradation in our society. There are different Hindi and English channels provocate our people to commit adultery. Young and middle aged people watching different television serials, television programs as a means of learning the tricks to spoil moral degradation. Watching these serials they become encourage to commit adultery relation with third party (The daily Jugantor, 4 April, 2018).Law of adultery should be reformed and our people should practice our own culture to stop adultery.

\section{Consequences of adultery}

Consequence is a result of a particular action or situation, often one that is bad or inconvenient. Adultery is one of the worst things that can happen to a marriage and violates everything you've built with your partner in such a personal way. Adultery results infidelity. Infidelity can feel like a death: the death of trust, the death of affection, the death of all the work you've done in your marriage. Once convinced that he or she married the wrong person in his or her life, the idea of divorce can take root and grow. Blinded by the deception of the affair, most people have no idea how they got there and don't know how to get out. There's no doubt about it that adultery affects marriages in the worst way. Adultery also often resulted in extreme violence, including murder (of the woman, her lover, or both, committed by her husband).Today, domestic violence is outlawed in most countries for adultery. In our country perspective, the common consequences of adultery are murder, divorce, deserted woman, spouse violence, domestic violence, flogging, sexually transmitted diseases etc.

\section{Violent crime and adultery}

When two people get involve in an illicit relationship, they forget to understand the right and wrong. They think only for their own benefit. Their family, children become valueless to them. In short, it can be said that become selfish is a common thing in adultery. They can do anything to maintain their illicit relationship. In such situation, to kill someone continuing their illegal relationship is not a big deal (Prothom Alo, 29 April,2018). Sometimes women are more at fault. Adultery makes a woman heartless and selfish. She involves in many violent crime to maintain her illegal relationship. Adultery leads a woman to commit violent crime. Mother is killing their own child for their extra marital affairs nowadays. At present killing husband and family members for their happiness are a regular news. All is happening because of adultery. Adultery is such a term which influences violent crimes like murder, honor killing, acid throwing, domestic violence etc. (bdnews24, 22 May, 2018)

\section{Adultery increases divorce}

Adultery increases divorce rate all over the world. Statistics vary on the subject but it's widely reported that 60 percent of men and 40 percent of women will participate in an extramarital affair at some point during their married life. Such negative emotions are hard to put behind you and many people feel there is no way to rebuild trust in the marriage. For example, In the United States, the divorce rate had risen steadily from 2.5 per 1000 population in 1966 to a peak of 5.3 in 1981[4]. Approximately 150,000 persons have been prosecuted annually for the crime of adultery since the 1980s in Hong Kong [9]. In India, divorce rate is also increasing for adultery. About $28.3 \%$ marriage are broken for adultery in India [17]. In Bangladesh, divorce rate is also increasing because of adultery. From the statistics of Dhaka City Corporation from 2010-2016, the total divorce amount is 52,000 which fundamental causes is adultery (bdnews24.com, 10June.2015). While adultery is no longer a deal breaker in many marriages, infidelity is one of the top cited reasons couples decide to get divorced. All over the world, adultery is a reason for increasing the rate of divorce[29]. The understanding between partners, unfaithfulness, cheating etc. is caused for adultery and divorce is the outcome of those causes. But it's not only effect those partners but also their children. The experts at Divorce Magazine note that about 45-50 percent of married women and 50-60 percent of married men cheat on their spouses. According to the American Psychological Association (APA), infidelity in the United States accounted for 20-40 percent of divorces. The APA also cited that 42 percent of divorced individuals reported more than one affair.(APA report,2010) In a Gallup poll, researchers noted that more than half (sixty-two percent) of partners say they would leave their spouse and get a divorce if they found out their spouse was having an affair; 31 percent would stick it out and not divorce. Adultery is still one of the most cited reasons for divorce.

\section{Adultery increases deserted woman}

Desertion has been seen throughout history but the phenomenon of wives deserted or abandoned by their husbands has been growing invasively for more than a decade, especially in South Asian and other developing countries across the world. Sometimes 
cultural, religious and social values are responsible for family desertion. For those reasons a man can continue a relationship easily with another woman keeping one wife at home or remarry and easily leave the first wife and her children. Bangladesh is predominantly a Muslim-populated country where Muslim marriage laws and Islamic religious law "shariah" permit polygamy .Extramarital relationship or adultery of the husband was the most common cause of desertion cases. Among ten respondents, five claimed that they were deserted by their husband due to his adultery or extra marital relation [18].

\section{Violence between the partners of an adulterous couple}

Married people who form relations with other partners may be subjected to violence in these relations [19]. Because of the nature ofadultery illicit or illegal inmany societies this type ofintimate partner violence maygo underreported or may not beprosecuted when it is reported and in some jurisdictions thistype of violence is not coveredby the specific domesticviolence laws [10].

\section{Adultery causes domestic violence}

Regrettably, this research testifies that usually in Bangladeshi culture, a married man and his family members remain vigilant about wife's infidelity or any pre-or extramarital affair. Seemingly, a wife also develops suspicion over her husband's affairs and remains scared of his second or any secret marriage [20]. Adultery is one of the very much important causes for violence against women. Main reason behind Violence against Women was dowry (32.72\%), familial conflict (32.54\%), sexual assault (19.16\%), extramarital relation $(11.20 \%)$, others $(3.06 \%)$ [21]. So this paper is right to say that Adultery occurs domestic violence.

\section{Flogging}

In some jurisdictions flogging is a punishment for adultery. There are also incidents of extrajudicial floggings, ordered by informal religious courts. In 2011, a 14-year-old girl in Bangladesh died after being publicly lashed when she was accused of having an affair with a married man. Her punishment was ordered by villagers under Sharia law (BBC News, 2017).

\section{Children are worst sufferer for adultery}

Children suffer most when their parents engage in extramarital affairs, even when the parents succeed in keeping the affairs secret. Therapists and sociologists are finding while an affair is taking place children sense that the parent is expending emotional energy outside the family. As a result, the children may become anxious or frightened or they may sense rejection and feel they must have done something wrong [11]. In our country, our people are not so much educated and conscious. When a family breaks up for adultery, the children fall in to a deep sea. They cannot get enough economic support for their life. They do not get emotional support, love from their parents. Even most of the time the children feel identity crisis. One of the major cause of juvenile delinquency is broken family (The daily Prothom Alo, 19 April,2018). When a children doesn't have any family bonding, he or she become frustrated and as a consequence they involve themselves in different types of violent activities. Moreover, experts found that such children are prone to have affairs themselves when they marry. Increasing clinical evidence and a recent study suggest that the subtle changes in an adulterous parent's behavior can unsettle children, regardless of whether the truth leaks out and even if the children are too young to understand what is happening.

\section{Sexually Transmitted Disease}

In today's world, sexually transmitted diseases are one of the greatest health risks and threats to the destruction of the human race. These terrible diseases cause blindness, insanity, and death. The uncontrolled spread of these diseases is an indication that something is terribly wrong with people's sexual behavior. The primary cause of sexually transmitted diseases is adultery, premarital sex, and sexual perversion of all kinds [23]. It is a fact that the largest populations being affected by these diseases are young people, homosexuals, and the third world nations. There is something terrible wrong with a society when sexual gratification is the primary factor in their decision making process and colors almost every aspect of their behavior.

In International perspective, besidethese consequences honor killing, stoning are also shown as a result of adultery.

\section{Honor killings}

Honor killings are often connected to accusations of adultery. Honor killings continue to be practiced in some parts of the world, particularly in parts of South Asia and the Middle East. Honor killings have also taken place in immigrant communities in Europe, Canada and the U.S. In some parts of the world. Honor killings enjoy considerable public support. In one survey, $33.4 \%$ of teenagers in Jordan's capital city, Amman, approved of honor killings (BBCNews, 2007). A survey in Diyarbakir, Turkey, found that, when asked the appropriate punishment for a woman who has committed adultery, $37 \%$ of respondents said she should be killed, while $21 \%$ said her nose or ears should be cut off. (BBC News, 2008). Until 2009, in Syria, it was legalfor a husband to kill or injure his wife or his female relatives caught in flagrante delicto committing adultery or other illegitimate sexual acts [24]. According to the UN in 2002, Honor killings had been practiced in Egypt, Jordan, Lebanon, Morocco, Pakistan, the Syrian Arab Republic, Turkey, Yemen, and other Mediterranean and Persian Gulf countries and that they had also taken place in western countries such as France, Germany and the United Kingdom within migrant communities. 


\section{Stoning}

Stoning refers to a form of capital punishment whereby an organized group throws stones at an individual until the person dies or the condemned person is pushed from a platform set high enough above a stone floor that the fall would probably result in instantaneous death. Stoning continues to be practiced today, in parts of the world. Recently, several people have been sentenced to death by stoning after being accused of adultery in Iran, Somalia, Afghanistan, Sudan, Mali, and Pakistan by tribal courts [24].

\section{Theoretical perspective}

There are various criminological theories which may describe adultery .Such as: Opportunity theory, Routine Activity theory, psychosexual theory, and rational choice theory, Marginalization theory but opportunity theory is the most appropriate theory which can describe adulterous behavior.

\section{Opportunity theory}

Adultery is the voluntary sexual relationship between a married woman and a third person. Without women participation adultery is impossible .This opportunity theory mainly discus about the opportunity of female partner and opportunity for communication tools.. In our present world, Women are getting more opportunity in all spheres of life. They are working in workplace with the male parts. They are also getting economic solvency. As they are getting more independency, they have more and more opportunity to run their own life according to their willingness. Many of our family also run by the female people. The numbers of female- headed households are also increasing in our country. Official estimates suggest that less than a tenth of households are headed by women [28] but another research found that the actual proportion could be around 20 to 30 percent [25]. When they are getting more opportunity, they can use different types of communication tools to communicate with others. By getting more opportunity they are involving to commit adultery. According to the empirical observations of opportunity theory, she argued that historically, males are more active in crime because of their greater social opportunities, competences and networking than females [26]. In the broader social context, if female opportunity, efficiency and social communication are increased, then the rate of female criminality increases accordingly [27]. Overall, the opportunity theory predicts that increasing opportunities of women increase the rate of female criminality [30]. To use the internet, mobile, phone they are involve to make extra marital relationship with a third party. In the past it is not possible to make an extra marital relationship so easily. Our internet, communication system makes it easy. By earning money woman can make also any illegal relationship with the third party. As they go outside for their own work, they can easily get chance to mix with her adultery partner. By getting more opportunity they are involving with adultery.

\section{CONCLUSION}

Adultery is not only a good ground for broken family but also a crime in Bangladesh. From this paper few points can be noted. Such as: There is a direct connection between the crime and adultery, relation between adultery and divorce, the causes of adultery and sexual crimes affect more on children, there are differences of adultery laws and punishment among different countries, the present condition of adultery, the consequences of adultery, psychological and physical effect because of adultery. Adultery is a selfish and very cruel act that happens every day. It is not only ruins marriages but it can literally destroy the lives of everyone around the adulterer. Someone who is a victim of adultery can be presented to large amounts of downfalls in their life. Emotional and mental abuses are two of the major things they will go through. If the case is bad enough and the person can't take mentally and emotionally dealing with what their spouse has done, adultery can even lead to death. It's mind boggling selfish act that can bring so much pain in many lives. Even more disturbing, the adulterer is rarely punished or held accountable for all the pain their actions inflicted on so many other lives. Adultery is nothing less than abuse and should be treated as such in a court of law. Our family, government, guardian, should become more conscious to get free from adultery. Mainly the marriage partner must play the main duty to decrease adultery. Both the husband and wife must give enough time to their life partner. People must keep an eye to use internet, watching television and involving virtual world. All this efforts can decrease the adultery in our country and help to make a happy society.

\section{REFERENCES}

1. Chowbe, V. (1991). Adultery-A conceptual \& legal analysis. Retrieved from http://ssrn.com/abstract=1856991

2. Atkins, D., Baucom, D., \& Jacobson, N. (2001). Understanding infidelity:Correlates in a National random sample. Journal of family psychology .

3. Wiederman, M. W. (1997). Extramarital sex: Prevalence and correlates in a national survey. Journal of Sex Research, 34(2), 167-174.

4. Ma, Q., \& Clarke, D. R. (1995). Size dependent hardness of silver single crystals. Journal of Materials Research, 10(4), 853-863.

5. Lauman, E., Gagnon, J., Michael, R., \& Michaels, S. (1994). The social organization of sexuality : Sexual practices in the united states. Chicago: University of Chicago press.

6. Akram, Saleh.(2017).A gender justice or injustice in case of adultery, Law journal BD,07

7. Weiss, Y., \& Willis, R. J. (1997). Match quality, new information, and marital dissolution. Journal of labor Economics, 15(1, Part 2), S293-S329. 
8. Lillard, L. A., \& Waite, L. J. (1990). Determinants of divorce. Social Security Bulletin, 53(2), 29-31.

9. Nwoye, A. (1991). Marriage and family counselling. Fab Education Books.

10. Durex. (2005). The global sex survey. Retrieved from http://www.durex.co.nz/aboutdurex/globalsexsurvey/

11. Choi, K. H., Catania, J. A., \& Dolconi, M. M. (1994). Extra marital sex and HIV risk behavior among US adults:results from the National AIDS behavioral survey. AM J public health.

12. Das, T. K., Alam, M. F., Bhattacharyya, R., \& Pervin, A. (2015). Causes and contexts of domestic violence: Tales of help- seeking married women in Sylhet, Bangladesh. Asian Social Work and Policy Review, 9(2), 163-176.

13. Religioustolerance. (2015, February 26). Punishment for adultery in Islam. Retrieved from www.religioustolerance.com.

14. Thestar. (n.d.). wills found guilty of murdering mistress. www.thestar.com.Retrieved from http://www.refworld.org/docid/3ae6b5bf0.html [accessed 28 June 2018]

15. Jane, S., Jaquette, S. L. Women and Democracy:Latin America and central and eastern europe

16. Human rights (Sexual conduct)act 1994. Retrieved from https://www.legislation.gov.au/Details/

17. Bindhu, Vasudevan., Geetha , Devi., Anitha Bhaskar., \& Binu, Areeka.(2015). Causes of divorce: A descriptive study from central Kerala, Journal of evolution of medical and dental sciences, 4, 3418-3426,

18. Ahmed, Neaz., Ahmmed, Faisal. (2015). Problems and challenges of desrted women in Bangladesh:an observational study. Journal of International Social Issues, 3, 1-11

19. Gu, G., Yuan, J., Wills, M., \& Kasper, S. (2007). Prostate cancer cells with stem cell characteristics reconstitute the original human tumor in vivo. Cancer research, 67(10), 4807-4815.

20. Das, T. K., Alam, M. F., Bhattacharyya, R., \& Pervin, A. (2015). Causes and contexts of domestic violence: Tales of help- seeking married women in Sylhet, Bangladesh. Asian Social Work and Policy Review, 9(2), 163-176.

21. Khan, N. T., Begum, A., Chowdhury, T. M. J., Das, B. K., Shahid, F., Kabir, S., \& Begum, M. (2017). Violence against women in Bangladesh. Delta Medical College Journal, 5(1), 25-29.

22. Tabassum, N., Nashid, Begum, A., \& Kumar, B. (2017). Violence against women in Bangladesh. Retrieved from http://www.observerbd.com/details.php/

23. Hirsch, A. R. (2009). Making the second ghetto: Race and housing in Chicago 1940-1960. University of Chicago Press.

24. Rapps, J. A. (1999). Testing a theoretical model of critical thinking and cognitive development.

25. Afsar, R. (1997). Onus of poverty on women in the poorer settlements of Dhaka City. Women and poverty.

26. Lui, Hon., \& Fan,Simon. (2010). Extra marital affairs,marital satisfaction and divorce:evidence from Hongkong. Retrieved from https://onlinelibrary.wiley.com/doi/abs/

27. Banarjee, S., Islam, M. J., \& Khatun, N. (2015). Theories of Female Criminality: A criminological analysis. International Journal of Criminology and Sociological Theory, 7(1).

28. Bangladesh bureau of statistics. (1996). Report of the poverty monitoring survey,Dhaka: Ministry of planning.

29. Chen, N. (2012). Extramarital Affairs in the Workplace .Retrieved from http://extension.missouri.edu/jackson/documents/A rticles/Relationships/ExtramaritalAffairsintheWork place/

30. Criminal Code of the Republic of China Article:239. Retrieved from https://www.oecd.org/site/adboecdanticorruptionini tiative/

31. Swiss Penal code Retrieved from https://www.admin.ch/ch/e/rs/3/311.0.en.pdf\&sa/ 